\title{
Mature autologous dendritic cell vaccines in advanced non-small cell lung cancer: a phase I pilot study
}

\author{
Maurício W Perroud Jr ${ }^{1}$, Helen N Honma ${ }^{1}$, Aristóteles S Barbeiro ${ }^{1}$, Simone CO Gilli', Maria T Almeida ${ }^{2}$, \\ José Vassallo ${ }^{3}$, Sara TO Saad ${ }^{2}$ and Lair Zambon ${ }^{1 *}$
}

\begin{abstract}
Background: Overall therapeutic outcomes of advanced non-small-cell lung cancer (NSCLC) are poor. The dendritic cell (DC) immunotherapy has been developed as a new strategy for the treatment of lung cancer. The purpose of this study was to evaluate the feasibility, safety and immunologic responses in use in mature, antigenpulsed autologous DC vaccine in NSCLC patients.

Methods: Five HLA-A2 patients with inoperable stage III or IV NSCLC were selected to receive two doses of $5 \times 10^{7}$ DC cells administered subcutaneous and intravenously two times at two week intervals. The immunologic response, safety and tolerability to the vaccine were evaluated by the lymphoproliferation assay and clinical and laboratorial evolution, respectively.

Results: The dose of the vaccine has shown to be safe and well tolerated. The lymphoproliferation assay showed an improvement in the specific immune response after the immunization, with a significant response after the second dose $(p=0.005)$. This response was not long lasting and a tendency to reduction two weeks after the second dose of the vaccine was observed. Two patients had a survival almost twice greater than the expected average and were the only ones that expressed HER-2 and CEA together.

Conclusion: Despite the small sample size, the results on the immune response, safety and tolerability, combined with the results of other studies, are encouraging to the conduction of a large clinical trial with multiples doses in patients with early lung cancer who underwent surgical treatment.
\end{abstract}

Trial Registration: Current Controlled Trials: ISRCTN45563569

\section{Background}

Lung cancer is the leading cause of cancer-related morbidity and mortality, resulting in more than 1 million deaths per year worldwide[1]. In Brazil, the current estimatives of incidence are 18.37/100.000 and 9.82/100.000 for men and women, respectively [2]. About $70 \%$ of patients with lung cancer present locally advanced or metastatic disease at the time of diagnosis, because there is no efficient method to improve the early diagnosis [3] and this fact has a huge impact on treatment outcomes. In spite of the aggressive treatment with

\footnotetext{
* Correspondence: lair.zambon@hes.unicamp.br

'Department of Internal Medicine, Faculty of Medical Sciences, State University of Campinas, Campinas, Brazil

Full list of author information is available at the end of the article
}

surgery, radiation, and chemotherapy, the long-term survival for patients with lung cancer still remains low. Even patients with early stage disease often succumb to lung cancer due to the development of metastases, indicating the need for effective approaches for the systemic therapy of this condition [4].

A variety of novel approaches are now being investigated to improve the outlook for management of this disease. Theories have also been postulated regarding the failure of the immune systems to prevent the growth of tumors. However, despite significant advances in our understanding of the molecular basis of immunology, many obstacles remain in translating this understanding into the clinical practice in the treatment of solid tumors such as lung cancer [1]. 
Dendritic cells (DCs) are the most potent antigen presenting cells with an ability to prime both a primary and secondary immune response to tumor cells. DCs in tumors might play a stimulating and protective role for effector T lymphocytes, and those DCs that infiltrate tumor tissue could prevent, by co-stimulating molecules and secreting cytokines, tumor-specific lymphocytes from tumor-induced cell death [5].

We believe that tumor vaccines may play an adjuvant role in NSCLC by consolidating the responses to conventional therapy. Then, we decided to conduct this study to evaluate the feasibility, safety, tolerability and immunologic responses in use in mature, antigen-pulsed autologous DC vaccine in a group of non-small cell lung cancer patients (NSCLC).

\section{Methods \\ Patient Characteristics}

Patients who met the following eligibility criteria were included: histopathologically confirmed diagnosis of advanced NSCLC (stage IIIB-IV) [6]; aged $\leq 70$ years; performance status $\leq 2$ [7]; no prior chemotherapy, surgery, or radiotherapy; no central nervous system metastases and at least one measurable lesion according to the RECIST's criteria [8]; no associated acute disease; HLA-A2 phenotype and expression of WT1 (Wilms Tumor Protein), HER-2 (Human Epidermal Growth Factor Receptor 2), CEA (Carcinoembryonic Antigen) or MAGE1 (Melanoma Antigen 1) proteins at the tumor site (tissue). The phenotype HLA-A2 was chosen due the methodology adopted for the incorporation of the antigen to the dendritic cell. The maintenance of organic functions was confirmed by: white blood cells (WBC) $\geq 3000 / \mathrm{mm}^{3}$, neutrophil cells $\geq 1500 / \mathrm{mm}^{3}$, hemoglobin $(\mathrm{Hgb}) \geq 9.0 \mathrm{~g} / \mathrm{dL}$, and platelets $\geq 100,000 / \mathrm{mm}^{3}$; bilirubin $\leq 1.5 \mathrm{mg} / \mathrm{dL}$, aspartate aminotransferase $\leq 40$ IU/L; creatinine clearance $>55 \mathrm{~mL} /$ minute. The written informed consent was obtained from all patients enrolled in the study. The study was conducted in accordance with the International Conference on Harmonization $(\mathrm{ICH})$ guidelines, applicable regulations and the guidelines governing the clinical study conduct and the ethical principles of the Declaration of Helsinki.

\section{Trial Design}

The trial was nonrandomized. All selected patients received conventional treatment (chemotherapy with or without radiotherapy). Briefly, the chemotherapy protocols included paclitaxel $175 \mathrm{mg} / \mathrm{m}^{2}$ and cisplatinum $70 \mathrm{mg} / \mathrm{m}^{2}$ on day 1 . These cycles were then repeated four times every 21 days. After the forth chemotherapeutical cycle, the patients were submitted to computed tomography (CT) scan of thorax, abdomen and brain to evaluate the tumor response. The progressive disease was an exclusion criterion. Patients who met all criteria for inclusion were eligible to the dendritic cells vaccine as an adjuvant therapy, which was administered after hematological recovery (platelets $\geq 70,000 / \mathrm{mm}^{3}$ ). The measurable immunologic response and safety to the vaccine were the primary and secondary endpoints. The small sample size could preclude meaningful assessment of therapeutic effects. The clinical tolerability was determined by routine safety laboratories and the clinical events described by the Cancer Therapy Evaluation Program (CTEP), and Common Terminology Criteria for Adverse Events (CTCAEv3) [9]. The steps of the study are showed in figure 1.

\section{Leukapheresis}

Fresenius Com.Tec (Fresenius Kabi - Transfusion Technology, Brazil) was used for all running procedures of the MNC program, at $1500 \mathrm{rpm}$, and with a P1Y kit. Plasma pump flow rates were adjusted to $50 \mathrm{~mL} / \mathrm{min}$. The volume processed ranged between patients and was determined by estimated cell count after $150 \mathrm{~mL}$ of processed blood. ACD-A was the anticoagulant used in these studies. The Inlet/ACD Ratio ranged from 10:1 to $16: 1$. There was no need for replacement, because the total volume of blood taken was less than $15 \%$.

\section{Microbiologic Monitoring}

Microbiological tests were performed at the beginning of the culture, on the fifth day and at the time of vaccine delivery. Samples were incubated for 10 days for the certification of absence of contamination.

\section{Generation of dendritic cells}

After informed consent, the mature dendritic cells of autologous mononuclear cells were isolated by the FicollHypaque density gradient centrifugation (Amersham, Uppsala, Sweden). Monocytes were then enriched by the Percoll hyperosmotic density gradient centrifugation followed by two hours of adherence to the plate culture. Cells were centrifuged at $500 \mathrm{~g}$ to separate the different cell populations. Adherent monocytes were cultured for 7 days in 6-well plates at $2 \times 10^{6}$ cells/mL RMPI medium (Gibco BRL, Paisley, UK) with $1 \%$ penicillin/streptomycin, $2 \mathrm{mM}$ L-glutamine, $10 \%$ of autologous, $50 \mathrm{ng} / \mathrm{mL}$ GM-CSF and $30 \mathrm{ng} / \mathrm{mL}$ IL-4 (Peprotech, NJ, USA ). On day 7 , the immature DCs were then induced to differentiate into mature DCs by culturing for 48 hours with 30 $\mathrm{ng} / \mathrm{mL}$ interferon gamma (IFN- $\gamma$ ).

According to the previous expression detected by immunohistochemistry, the HLA-A2 restricted to WT1 peptide (RMFPNAPYL), CEA peptide (YLSGANLNL), MAGE-1 peptide (KVAELVHFL), and HER-2 peptide (KIFGSLAFL) were pulsed to the DC culture (day 9) at the concentration of $25 \mathrm{ug} / \mathrm{mL}$ and incubated for 24 hours to the vaccine administration. 


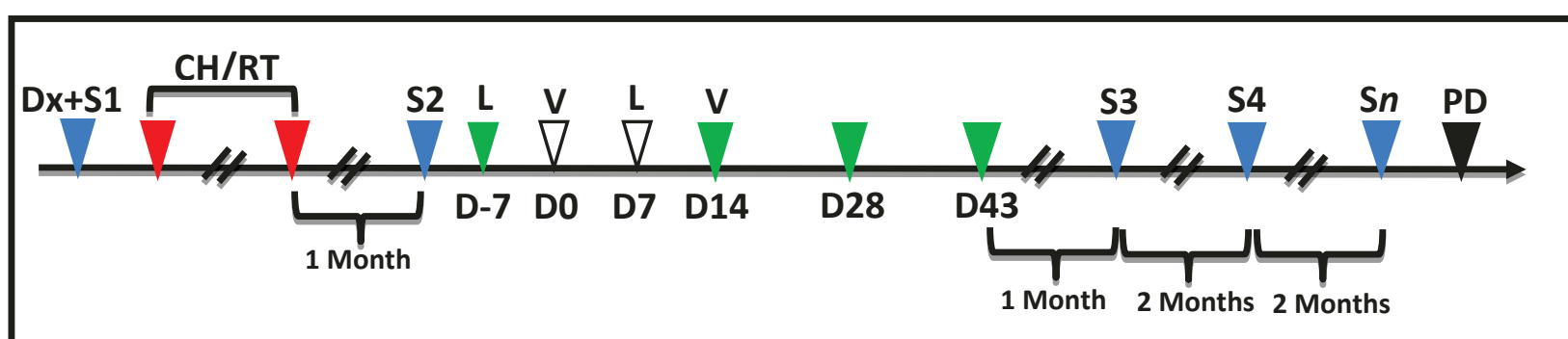

Figure 1 The steps of the study. Leukapheresis' day is marked with "L" (D-7 and D7). Immunizations' day is marked with "V" (D0 and D14). Blue triangle - Evaluation step: "Dx+S1" = Diagnosis and 1 ${ }^{\text {st }}$ Radiologic Staging; "S2" $=2^{\text {nd }}$ Radiologic Staging (1 month after conventional treatment); "S3" $=3^{\text {rd }}$ Radiologic Staging (1 month after vaccine); "S4...Sn" = Radiologic staging was repeated every 2 months until the progression of the disease ("PD" - black triangle). Red triangle - Conventional treatment (chemo/radiotherapy). Green triangle - Lymphoproliferation test; it was done before immunization on D0 and D14.

\section{Flow cytometry}

DC were harvested on day 7 and washed with PBS. Fluorescent conjugated monoclonal antibodies targeted against the following antigens were used for phenotypic analysis: CD14 (PerCp), CD80 (Pe), CD83 (APC), CD86 (Fitc), HLA-A (Fitc), HLA-DR (Pe-Cy7), CD11c (Pe), CD40 (PerCp-Cy5.5), CCR5 (Pe), CCR7 (Fitc), IL$10(\mathrm{Pe})$ and IL-12p70 (Fitc) (Caltag, Burlingame, CA, USA). Antibodies targeted against CD3 (Pe), CD8 (PECy7), CD4 (PerCp) and IFN $\gamma$ (Fitc) were used for phenotypic analysis of lymphocyte after the lymphoproliferation assay. Isotype-matched antibodies were used as controls (Caltag, Burlingame, CA, USA). The labeling was carried out at room temperature for $30 \mathrm{~min}$ utes in PBS. For the intracellular labeling (IL-10 and IL-12p70), cells were permeabilized and fixed using the Fix-Cells Permeabilization Kit (Caltag, Burlingame, CA, USA). After labeling, cells were washed twice in PBS and analyzed by a FACSArea cytometry using the CELL QUEST PRO software application. The DC and lymphocyte populations were gated based on their forward-scatter and side-scatter profile (large or small granular cell population, respectively). The results are expressed as percentage of positive cells and for IL-12 and IL-10 expression, the mean fluorescence intensity was also observed.

\section{CFSE Labeling}

PBMCs $\left(1 \times 10^{7}\right)$ were incubated at $37^{\circ} \mathrm{C}$ for $15 \mathrm{~min}$ in $1 \mathrm{~mL}$ of PBS containing CFSE (Molecular Probes Europe, Leiden, The Netherlands) at $0.6 \mu \mathrm{M}$, a concentration which was determined in preparatory experiments as useful. After one washing step in PBS containing 1\% FCS, the cells were re-suspended at a density of $1 \times 10^{6}$ cells $/ \mathrm{mL}$ and used to perform the lymphoproliferation assay. After 6 days of incubation, the CFSE-labeled cells were washed once in PBS and then either immediately fixed in PBS containing 4\% formaldehyde, and subjected to analysis by a FACSArea and CellQuest software (BD, Mountain View, CA, USA). The CFSE-fluorescence was plotted against forward scatter. The retained bright CFSE staining consistent with no proliferative response and the lost CFSE-fluorescence indicated an induced proliferation. The reduced level of CFSE staining in the stimulated lymphocyte in relation to the unstimulated was used to calculate a proliferation index.

\section{Immunization Protocol}

A prime vaccine and a single boost were given fifteen days apart. For each dose of vaccine, two aliquots were prepared in separated syringes with saline solution (500 $\mu \mathrm{l} /$ dose) containing $5 \times 10^{7}$ cells. First, a dose was subcutaneously administered in the arm and after 1 hour the second dose was given intravenously in the other arm. After the second dose, the patient remained under observation for 1 hour for evaluation of immediate unexpected adverse events.

\section{Clinical Evaluation}

The follow-up included routine history and physical exam, chest $\mathrm{x}$-ray and computed tomography scans at regular intervals post immunization or as directed by signs or symptoms of tumor recurrence.

\section{Immunologic Assessment}

\section{A. Phenotypic characterization of immune cells from patients' peripheral blood}

The cellular composition of the immune system, before and after vaccination with the dendritic cells, was assessed from peripheral blood samples using flow cytometry. The day of immunization was considered as "Day 0 ". The peripheral blood samples were collected one week before vaccination ("Day -7"), two weeks after the first dose of vaccine ("Day 14"), two weeks after the second dose of vaccine ("Day 28") and one month ("Day 43 ") after the end of the vaccination protocol. 
Surface antigens labeled with specific fluorochromes for T lymphocytes (CD4 and CD8), NK cells (CD56), B lymphocytes (CD19) and mature dendritic cells (CD86, CD80, CD83, CD40 and HLA-DR) were used for immunophenotyping of the patients' blood cells.

Approximately $2 \times 10^{5}$ cells per test were treated with a lysis solution for the red blood cells, centrifuged at $300 \mathrm{~g}$ for 5 minutes, rinsed with PBS and re-suspended in $100 \mu \mathrm{l}$ of cytometry buffer (PBS with $0.5 \%$ bovine serum albumin and $0.02 \%$ sodium azide). Subsequently, these cells were incubated in the dark for 30 minutes at $4^{\circ} \mathrm{C}$ with monoclonal antibodies labeled with the specific fluorochromes described above. Then the samples were washed twice with flow cytometry buffer, fixed with paraformaldehyde and analyzed by a flow cytometer (FACSCalibur - Becton Dicknson).

\section{B. Analysis of the specific immune response in vitro by flow} cytometry

The lymphoproliferation test was used to assess the ability of dendritic cells to stimulate specific lymphocytes in vivo.

\section{Collection of T lymphocytes}

The peripheral blood samples collected at the times describes above were enriched with $\mathrm{T}$ lymphocytes $\left(\mathrm{CD}^{+}\right)$by negative immune selection with immunomagnetic beads specific for NK cells $\left(\mathrm{CD} 56^{+}\right)$, B lymphocytes $\left(\mathrm{CD} 19^{+}\right)$and monocytes $\left(\mathrm{CD} 14^{+}\right)$.

The cells collected before vaccination were centrifuged at $600 \mathrm{~g}$ during 10 minutes and the cell pellet was washed twice with PBS, re-suspended in RPMI with 1\% human $\mathrm{AB}$ serum and 10\% dimethyl sulfoxide and then frozen to $-90^{\circ} \mathrm{C}$ at a controlled rate of $1^{\circ} \mathrm{C} /$ minute until the time of the first test (two weeks after the first dose of the vaccine).

\section{Lymphoproliferation assay}

The $\mathrm{T}$ cells $\left(1 \times 10^{6} \mathrm{cels} / \mathrm{mL}\right)$ were re-suspended in 1 $\mathrm{mL}$ of PBS containing $0.25 \mu \mathrm{M}$ of CFSE (Molecular Probes, The Netherlands) and incubated for 15 minutes at $37^{\circ} \mathrm{C}$. After this incubation period, the cells were washed twice with RPMI 1640 supplemented with $1 \%$ human $\mathrm{AB}$ serum cold by centrifugation at $600 \mathrm{~g}$ for 10 minutes and incubated in ice for 5 minutes.

After this period, the cells were again centrifuged at $600 \mathrm{~g}$ for 10 minutes and re-suspended in the same medium supplemented with $25 \mathrm{ng} / \mathrm{mL}$ of IL-7. These lymphocytes were cultivated in 24 -well plates $\left(1 \times 10^{5}\right.$ cells/well) with $25 \mu \mathrm{g} / \mathrm{mL}$ of each tumor peptide defined for each patient, separately. This culture was incubated for 4 days at $37^{\circ} \mathrm{C}$ in $5 \% \mathrm{CO}_{2}$.

The percentage of proliferation was calculated using the number of cells with CFSE labeling using the following formula: [(Number of CFSE-labeled cells in the test group - Number of CFSE-labeled cells in the control group)/Number of CFSE-labeled cells in the control] $\times$
100. As for the control, the same test was performed using unstimulated lymphocytes labeled with CFSE. All tests had been carried out in triplicate.

The results of the lymphoproliferation were compared using Wilcoxon signed ranks test.

\section{Results}

\section{Patient Characteristics}

Between June/2006 and August/2008, 48 patients were evaluated. Only five patients met all criteria for inclusion in the study. The median age was 60 years and 3 of 5 patients were males. The histologic subtypes were as follows: adenocarcinoma (2), invasive mucinous adenocarcinoma (former bronchioloalveolar) (1), squamous cell carcinoma (1) and adeno/squamous cell carcinoma (1). Four patients were stage IIIB and one was stage IV at the time of the diagnosis. The patients' characteristics are summarized in Table 1.

\section{Safety}

During the chemo and radiotherapy, no adverse events grade $>2$ were reported. No reaction was observed during or after the leukapheresis. No local reaction was observed at the vaccine site of application. One patient presented systemic reactions after the immunotherapy. This patient developed fatigue (grade 2) and chills five days following the first dose of the vaccine and was hospitalized on the $7^{\text {th }}$ day because the laboratorial analyses showed leukopenia $\left(1,500 / \mathrm{mm}^{3}\right.$; grade 3$)$, granulocytopenia $\left(900 / \mathrm{mm}^{3}\right.$; grade 3$)$, lymphopenia $(495 / \mathrm{mm} 3$; grade 3$)$; thrombocytopenia $(88,000 / \mathrm{mm} 3$; grade 1$)$; anemia (hemoglobin 8,5 g/dL; grade 2) and hyponatremia (126 mEq/L; grade 3). The serology to the Human Immunodeficiency Virus (HIV), mononucleosis, cytomegalovirus, Epstein Barr, Mycoplasma pneumoniae and dengue were negatives, as well as the bacterial cultures. Cephepime was prescribed empirically. No colony-stimulating factor was used and the patient recovered from blood changes, spontaneously, after five days, except by the anemia. The hyponatremia was treated with sodium replacement and became normal after one week.

\section{Immunologic responses to Vaccines}

The lymphoproliferation assay showed an improvement in the specific immune response after the immunization. This response was not long lasting and a tendency to reduction 2 weeks after the second dose of the vaccine was observed.

Patterns of reactivity ranged between individuals (Figure 2). Two patients (\#3 and \#5) expressed a noteworthy result at the lymphoproliferation tests at one time point after the first dose. Patients \#1 and \#4 presented a visibly boosted response temporally related to the second dose. Patient \#2 showed a mixed response 
Table 1 Patient characteristics

\begin{tabular}{|c|c|c|c|c|c|c|c|c|c|c|c|c|c|}
\hline $\begin{array}{l}\text { Patient } \\
\text { ID }\end{array}$ & Sex & Age & Histology & $\begin{array}{l}\text { Stage at } \\
\text { enrollment }\end{array}$ & $\mathrm{ECOG}^{*}$ & Expression & $\begin{array}{l}\text { Therapy } \\
\text { Sequence }\end{array}$ & $\begin{array}{l}\text { Time between } \\
\text { the treatment } \\
\text { modalities } \\
\text { (days) }\end{array}$ & $\begin{array}{l}\text { Response to the } \\
\text { conventional } \\
\text { treatment } \\
\text { (RECIST) }\end{array}$ & $\begin{array}{c}\text { Time to } \\
\text { progression } \\
\text { from } \\
\text { Chemotherapy } \\
\text { (days) }\end{array}$ & $\begin{array}{c}\text { Time to } \\
\text { progression } \\
\text { from } \\
\text { Immunotherapy } \\
\text { (days) }\end{array}$ & $\begin{array}{l}\text { Survival } \\
\text { from } \\
\text { Diagnosis } \\
\text { (days) }\end{array}$ & $\begin{array}{l}\text { Survival from } \\
\text { Immunotherapy } \\
\text { (days) }\end{array}$ \\
\hline 1 & M & 61 & $\mathrm{Sq} / \mathrm{Ad}$ & IIIB $(T 4, N 2)$ & 1 & $\begin{array}{l}\text { HER-2 (grade 3) } \\
\text { MAGE1 (grade } \\
\text { 5) }\end{array}$ & $C T-I T$ & 77 & Partial Response & 138 & 47 & 258 & 84 \\
\hline 2 & M & 66 & $\mathrm{Ad}$ & IIIB $(T 2, N 3)$ & 2 & $\begin{array}{l}\text { WT1 (grade 4) } \\
\text { CEA (grade 6) }\end{array}$ & $C T-I T-X R T$ & $38 ; 3$ & Stable disease & 112 & 60 & 358 & 198 \\
\hline 3 & M & 59 & $\mathrm{Ad}$ & IIIB $(T 4, N 2)$ & 1 & CEA (grade 7) & $C T-X R T-I T$ & $30 ; 52$ & Stable disease & 231 & 82 & 276 & 112 \\
\hline 4 & $\mathrm{~F}$ & 63 & IMA & $\begin{array}{l}\text { IV }(\mathrm{T} 4, \mathrm{~N} 2, \\
\mathrm{M} 1)^{\#}\end{array}$ & 2 & $\begin{array}{l}\text { WT1 (grade 2) } \\
\text { CEA (grade 7) } \\
\text { HER-2 (grade 1) }\end{array}$ & $C T-I T-C T$ & $45 ; 56$ & Stable disease & 64 & 1 & 329 & 82 \\
\hline 5 & F & 50 & $\mathrm{Sq}$ & IIIB $(T 4, N 2)$ & 1 & $\begin{array}{l}\text { CEA (grade 3) } \\
\text { HER-2 (grade 2) }\end{array}$ & $C T-X R T-I T$ & $51 ; 56$ & Partial Response & 200 & 22 & 560 & 277 \\
\hline
\end{tabular}

Sq, squamous cell carcinoma; Ad, adenocarcinoma; IMA, invasive mucinous adenocarcinoma.

*ECOG: Eastern Cooperative Oncology Group performance status.

\#T4lpsi Nod, N2,M1aCont Nod. 


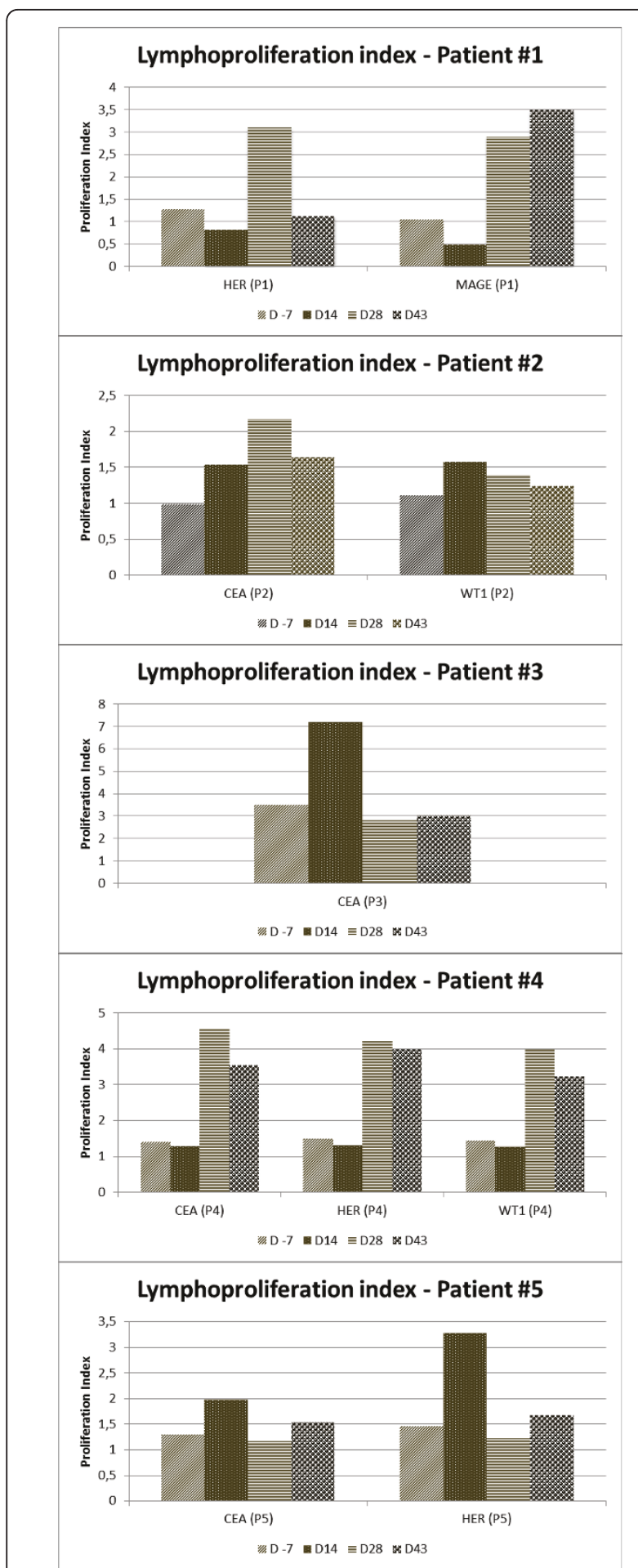

Figure 2 Immunological response. Lymphoproliferation index: " $D$ -7 " (1 week before $1^{\text {st }}$ dose); "D 14" (2 weeks after $1^{\text {st }}$ dose); " $D$ 28" ( 2 weeks after $2^{\text {nd }}$ dose); "D 43" (4 weeks after $2^{\text {nd }}$ dose); HER, human epidermal growth factor receptor; MAGE, melanoma antigen; CEA, carcinoembryonic antigen; WT1, Wilms tumor protein; P1, patient 1; P2, patient 2; P3, patient 3; P4, patient 4; P5, patient 5.

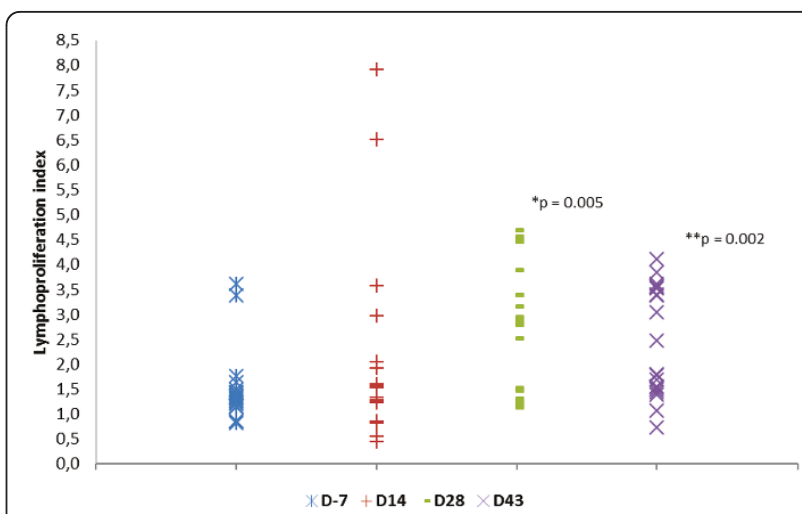

Figure 3 Immunological response. Lymphoproliferation's results from all patients and all antigens were compared using Wilcoxon signed ranks test. "D -7" (Median = 1.33; Min = 0.81; $\operatorname{Max}=3.59$ ); " $\mathrm{D}$ 14" (Median = 1.42; Min = 0.44; Max = 7.90); "D 28" (Median = 2.86; Min = 1.13; Max =4.68); "D 43" (Median 2.13; Min = 0.72; Max= 4.10). The difference was significant between " $D-7$ " and "D 28" $\left({ }^{*} p=0.005\right)$ and "D-7" and "D-43" (** $\left.p=0.002\right)$.

with a strongest response after the first dose to WT1 and a boosted response to CEA.

All the results of the lymphoproliferation assay - all patients and all antigens - are showed in Figure 3. These results were compared using Wilcoxon signed ranks test. The difference between "D-7" and "D 14" was not significant $(p=0.135)$. However, the difference was significant between "D -7" and "D 28" $(p=0.005)$ and between "D -7" and "D 43" ( $p=0.002)$.

\section{Clinical outcomes}

The clinical follow-up was available for all individuals for a minimum of 8.5 months from the diagnosis and almost 3 months from de second dose of immunotherapy. Data are presented in Table 1. Two individuals had partial response to the conventional therapy, while three had a stable disease. All of them received chemotherapy and those three were submitted to radiotherapy as well. Patient \#2 underwent immunotherapy previous to the radiotherapy. From the last dose of the vaccine, the time to the disease progression and survival ranged between 1 to 82 and 82 to 277 days, respectively. One day after immunotherapy, the Patient \# 4 presented worsening of the cough accompanied by progressive dyspnea. The follow up showed progressive disease on the radiologic exams.

\section{Discussion}

Despite the developments on chemo and radiotherapy, the 5 year survival rate improved only $3 \%$ (13 to $16.2 \%$ ) between 1975 and 2002 [10]. This fact occurs mainly because there is not an efficient screening method for 
the early diagnosis and it also shows that new therapeutic modalities are necessary.

Based on the antigen specificity of the immune system and the safety profile of cancer vaccines, the effective immunotherapy would be an ideal adjuvant, following initial clinical responses to definitive therapy [11]. The antigen-presenting cells, like dendritic cells, play an important role in the induction of an immune response, and an imbalance in the proportion of macrophages, immature and mature dendritic cells within the tumor could significantly affect the immune response to cancer [4].

Even though there have been numerous clinical trials for various types of cancer, there are few DC vaccines trials in patients with lung cancer, and many aspects related to the immunotherapy - like maximum dose, administration schema, response and safety - are unknown.

Our study was done with two aliquots of $5 \times 10^{7}$ cells for each dose. This dose is similar to that of other studies that used doses ranging between 8.2 and $10 \times 10^{7}$ cells [11-13]. Another trial demonstrated that a dose of $1.2 \times 10^{7}$ cells did not reach a truly maximum tolerated dose [14]. Given that there is no clear consensus about whether or not the route of immunotherapy influences on the efficacy of the vaccine, we chose to apply it by a subcutaneous and intradermal route.

In addition to the high level dose, the vaccine was well-tolerated as noted in many studies [11-15], even in a study in Hepatitis C Virus (HCV) infected individuals [16]. We observed no local reaction, but one patient presented fatigue, chills, pancytopenia and hyponatremia five days after the first dose of the vaccine. Usually, the reactions after immunotherapy occur within 24-48 hours after the infusion [12,17]. Therefore, we hypothesize that the patient developed an infection, but it cannot be proved because the bacterial cultures and viral tests were negatives.

Three patients had a longer time survival than expect for their TNM stage. Two of these (patients \#4 and \#5) had a survival almost twice greater than the expected average and they were the only ones that expressed HER2 and CEA together. Although the small sample size precludes the meaningful assessment of the therapeutic effects and any results may be due to chance, we cannot exclude that these clinical outcomes may indicate some therapeutic efficacy. Many variables related to the host and the vaccine may be important to reach therapeutic efficacy. The immunologic resistance of a tumor to immune effector cells at the local level remains a potential limitation to the vaccine efficacy, and the choice of antigens is also relevant to the therapeutic efficacy and potentially to the immunologic responses to vaccines [12]. Furthermore, the characteristics of the tumor antigen may change and it can become unresponsive to the initial tumor-antigen targeted therapy as tumors grow during conventional therapy $[14,15]$. We decided to produce a multivalent vaccine according to each patient tumor's antigen expression, observed by immunohistochemistry, to avoid this phenomenon and improve the results of immunotherapy by inducing a broad repertoire of antigen-specific $T$ cells [15]. Indeed, the profile of antigens with better therapeutic responses has not yet been determined.

The patterns of reactivity ranged between individuals (Figure 2). Two patients expressed a significant immunologic reaction after the first dose; another two presented a boosted response after the second dose and one showed a mixed response. The lymphoproliferation assay showed an improvement in the specific immune response after the immunization (Figure 3). However, this response was not long lasting and a tendency to reduction 2 weeks after the second dose of the vaccine was observed. This finding is consistent with other studies that showed a booster response to subsequent immunization $[11,12]$. The trend to return to baseline after an increase of reactive $\mathrm{T}$ cells might be viewed as a transient response [11], associated to the immunosuppressive environment within a tumor mass. It turns the vaccination protocol into a tiresome activity given that multiples doses may be required to reach clinical efficacy.

\section{Conclusion}

Despite the small sample size, the results on the immune response and safety, combined with the results from other studies, are encouraging to the conduction of a clinical trial with multiples doses in patients with early lung cancer who underwent surgical treatment. The DC vaccine could be a hopeful adjuvant therapeutic modality for this group of patients because they do not present a gap to antigenic changes or a bulky disease.

\section{List of Abbreviations}

DC: dendritic cell; NSCLC: non-small-cell lung cancer; WT1: Wilms Tumor Protein; HER-2: Human Epidermal Growth Factor Receptor 2; CEA: Carcinoembryonic Antigen; MAGE1: Melanoma Antigen 1.

\section{Acknowledgements and Funding}

Funding: This study was supported by grant number 401327/05-1 from the National Council for Scientific and Technological Development (CNPq), Brazil. We thank the Department of Radiology of the Hospital Estadual Sumaré UNICAMP for support in carrying out the imaging methods.

\section{Author details}

Department of Internal Medicine, Faculty of Medical Sciences, State University of Campinas, Campinas, Brazil. ${ }^{2}$ Hemocentro, State University of Campinas, Campinas, Brazil. ${ }^{3}$ Laboratory of Investigative and Molecular Pathology-CIPED, Faculty of Medical Sciences, UNICAMP - Campinas, São Paulo, Brazil. 


\section{Authors' contributions}

STS and LZ conceived the design of the study, participated in data analysis and were in charge of its coordination. JV and $\mathrm{HNH}$ processed the tumor tissue and performed the immunohistochemistry. ASB and MWP cared for the patients during the conventional treatment. MWP and SCOG cared for the patients during the immunotherapy, participated in data analysis, performed data interpretation and drafted the manuscript. MTA conducted the laboratory procedures to produce the DC vaccine, supported by SCOG. All authors read and approved the final manuscript.

\section{Competing interests}

The authors declare that they have no competing interests.

Received: 16 April 2011 Accepted: 17 June 2011

Published: 17 June 2011

\section{References}

1. O'Mahony D, Kummar S, Gutierrez ME: Non-small-cell lung cancer vaccine therapy: a concise review. J Clin Oncol 2005, 23:9022-9028.

2. Estimativa 2010 - Incidência de Câncer no Brasil - 2010 - INCA. [http:// www.inca.gov.br/estimativa/2010/index.asp?link=tabelaestados.asp\&UF=BR]

3. Molina JR, Yang P, Cassivi SD, Schild SE, Adjei AA: Non-Small Cell Lung Cancer: Epidemiology, Risk Factors, Treatment, and Survivorship. Mayo Clinic Proceedings 2008, 83:584-594.

4. Baleeiro RB, Anselmo LB, Soares FA, Pinto CAL, Ramos O, Gross JL, Haddad F, Younes RN, Tomiyoshi MY, Bergami-Santos PC, Barbuto JAM: High frequency of immature dendritic cells and altered in situ production of interleukin-4 and tumor necrosis factor-alpha in lung cancer. Cancer Immunol Immunother 2008, 57:1335-1345.

5. Tabarkiewicz J, Rybojad P, Jablonka A, Rolinski J: CD1C+ and CD303+ dendritic cells in peripheral blood, lymph nodes and tumor tissue of patients with non-small cell lung cancer. Oncol Rep 2008, 19:237-243.

6. Detterbeck FC, Boffa DJ, Tanoue LT: The new lung cancer staging system. Chest 2009, 136:260-271.

7. Oken MM, Creech RH, Tormey DC, Horton J, Davis TE, McFadden ET, Carbone PP: Toxicity and response criteria of the Eastern Cooperative Oncology Group. Am J Clin Oncol 1982, 5:649-655.

8. Therasse P, Arbuck SG, Eisenhauer EA, Wanders J, Kaplan RS, Rubinstein L, Verweij J, Van Glabbeke M, van Oosterom AT, Christian MC, Gwyther SG: New guidelines to evaluate the response to treatment in solid tumors. European Organization for Research and Treatment of Cancer, National Cancer Institute of the United States, National Cancer Institute of Canada. J Natl Cancer Inst 2000, 92:205-216.

9. ctcaev3.pdf (objeto application/pdf). [http://ctep.cancer.gov/ protocoldevelopment/electronic_applications/docs/ctcaev3.pdf].

10. Altekruse SF, Kosary CL, Krapcho M, Neyman N, Aminou R, Waldron W, Ruhl J, Howlader N, Tatalovich Z, Cho H, Mariotto A, Eisner MP, Lewis DR, Cronin K, Chen HS, Feuer EJ, Stinchcomb DG, Edwards BK: SEER Cancer Statistics Review, 1975-2007.Edited by: Bethesda, MD. National Cancer Institute; [http://seer.cancer.gov/csr/1975_2007/], based on November 2009 SEER data submission, posted to the SEER web site, 2010

11. Hirschowitz E, Foody T, Hidalgo G, Yannelli J: Immunization of NSCLC patients with antigen-pulsed immature autologous dendritic cells. Lung Cancer 2007, 57:365-372.

12. Hirschowitz EA: Autologous Dendritic Cell Vaccines for Non-Small-Cell Lung Cancer. Journal of Clinical Oncology 2004, 22:2808-2815.

13. Avigan DE, Vasir B, George DJ, Oh WK, Atkins MB, McDermott DF, Kantoff PW, Figlin RA, Vasconcelles MJ, Xu Y, Kufe D, Bukowski RM: Phase I/ II study of vaccination with electrofused allogeneic dendritic cells/ autologous tumor-derived cells in patients with stage IV renal cell carcinoma. J Immunother 2007, 30:749-761.

14. Um S, Choi YJ, Shin H, Son CH, Park Y, Roh MS, Kim YS, Kim YD, Lee S, Jung MH, Lee MK, Son C, Choi PJ, Chung J, Kang C, Lee E: Phase I study of autologous dendritic cell tumor vaccine in patients with non-small cell lung cancer. Lung Cancer 2010, 70:188-194.

15. Berntsen A, Trepiakas R, Wenandy L, Geertsen PF, thor Straten P. Andersen MH, Pedersen AE, Claesson MH, Lorentzen T, Johansen JS, Svane IM: Therapeutic dendritic cell vaccination of patients with metastatic renal cell carcinoma: a clinical phase 1/2 trial. J Immunother 2008, 31:771-780.
16. Gowans EJ, Roberts S, Jones K, Dinatale I, Latour PA, Chua B, Eriksson EMY, Chin R, Li S, Wall DM, Sparrow RL, Moloney J, Loudovaris M, Ffrench R, Prince HM, Hart D, Zeng W, Torresi J, Brown LE, Jackson DC: A phase I clinical trial of dendritic cell immunotherapy in HCV-infected individuals. J Hepatol 2010, 53:599-607.

17. McNeel DG, Dunphy EJ, Davies JG, Frye TP, Johnson LE, Staab MJ, Horvath DL, Straus J, Alberti D, Marnocha R, Liu G, Eickhoff JC, Wilding G: Safety and Immunological Efficacy of a DNA Vaccine Encoding Prostatic Acid Phosphatase in Patients With Stage D0 Prostate Cancer. Journal of Clinical Oncology 2009, 27:4047-4054.

doi:10.1186/1756-9966-30-65

Cite this article as: Perroud et al:: Mature autologous dendritic cell vaccines in advanced non-small cell lung cancer: a phase I pilot study. Journal of Experimental \& Clinical Cancer Research 2011 30:65.

\section{Submit your next manuscript to BioMed Central and take full advantage of:}

- Convenient online submission

- Thorough peer review

- No space constraints or color figure charges

- Immediate publication on acceptance

- Inclusion in PubMed, CAS, Scopus and Google Scholar

- Research which is freely available for redistribution

Submit your manuscript at www.biomedcentral.com/submit
Biomed Central 